\title{
ANALYSES OF ROCK SURFACE COLOUR CHANGES DUE TO WEATHERING
}

\author{
${ }^{1}$ Mehmet Kemal GOKAY \\ ${ }^{1}$ Selcuk University, Mining Engineering Department, Campus, Selcuklu, Konya, TURKEY \\ 1mgokay@selcuk.edu.tr
}

(Geliş/Received: 16.03.2017; Kabul/Accepted in Revised Form: 21.07.2017)

\begin{abstract}
Description parameters of rock masses and minerals include their colours as well. Colours appear in daylight for surfaced rock masses are changing slightly due to weathering layers which have been covering its surface gradually. Healthy human eyes can manage to differentiate visible light spectrum to identify colours of substances including rock masses. Then visible blackish colours of magnetite minerals, reddish colours of Terra- Rosa soils, greenish colours of weathered copper ore, pure white of salt minerals and many others are differentiable by naked eyes. Different colours and homogeneity of colour distribution for natural rocks are also main grading parameters of natural rock surfaces. In addition, colour can also be parameter to identify weathered rock surfaces. Outcrop rock mass surfaces or rock discontinuity surfaces which could be influenced by weathering factors, have their altered surface colours in general that, those colours can be different from the original rock colours. In this study, colour changes were determined in digital manner by obtaining rock surfaces' Red, Green, Blue digital colour (RGB) values. Digital colour differences have been then analyzed more specifically to evaluate rock weathering and colour changes.
\end{abstract}

Key Words: Color analyses, Colour change, Decolourisation, Rock weathering,

\section{Kaya Yüzey Renklerinde Bozuşma Sonucu Oluşan Değişimin İncelenmesi}

ÖZ: Kayaçları ve onları oluşturan mineralleri tanımlama işleminde, gözlenen kayaç ve mineral yüzey renklerinin farklılığı, onları tanımlama işleminde önemli bir yer tutmaktadır. Kaya kütleleri bulundukları lokasyonlarda, derinliklerde veya yeryüzünde, farklı etkilerden dolayı zaman içinde alterasyona uğrayarak bozuşurlar. Bu kayaç kütlelerinin sediman haline gelirken geçirdikleri kaçınılmaz kayaç döngüsünün önemli bir parçasıdır. Kayaçlardaki bozuşma çoğu durumda kayaç renginde önemli değişikliklere neden olur. Bu değişim sağlıklı insan gözleri tarafından algılanabilecek seviyede veya daha düşük seviyelerde gerçekleşebilir. İnsanlar çevrelerindeki kayaçları ve mineralleri onların renginden tanımlayabilirler. Manyetit mineralinin siyahlığı, terra-rosa toprağının kırmızı rengi, bozuşmuş bakır cevherinin yeşilliği, tuz mineralinin beyazlığ 1 ve daha birçok mineral ve kayaç rengi bunları tanımlamak için kullanılmaktadır. Kayaç yüzeylerindeki renkler, bunların dağılımı ve renklerin homojenliği, kayaçlarda gerçekleşen bozuşmanın derecelendirilmesinde kullanılan parametrelerdendir. Kayaç yüzey renkleri, bu yüzeylerde bozuşma olup olmadığını anlamada karar verici özellik taşırlar. Kayaçların gün yüzüne çıkmış yüzeyleri ve kayaç içindeki süreksizlik yüzeyleri, bu yüzeyleri etkisi altına alan bozuşma, başkalaşım, faktörleri nedeniyle renk değiştirmeye açıtır. Bu araştırma kapsamında, kayaç yüzeylerindeki bozuşmaya bağlı renk değişimleri sayısallaştırılarak analiz edilmiştir. İncelemeye alınan lokasyonlarda, yeni kırılmış-bozuşmamış kayaç yüzeyleri ve bozuşmaya uğramış kayaç yüzey renkleri Kırmızı (R), Yeşil (G), Mavi (B) renk kodlamasına sahip, RGB renk sistemine göre sayısallaştırılarak ayrı ayrı incelenmiştir. Farklı kayaçlardan elde edilen kayaç yüzey renkleri, RGB kodlamaları, bu çalışma kapsamında kendi aralarında değerlendirmeye alınarak, renklerdeki değişimler incelenmiştir. 


\section{INTRODUCTION}

Rock masses were early solid materials in the earth. After their first solidification, earth crust has been repeated its rock mass regeneration from mantle together with its demolishing process. Crustal movements, climate, sun radiation, chemical reactions, magmatic inner crust and volcanic activities have been main factors influencing these progressions. It is obvious that each volcanic discharge from magma has its own mineral mixture which turns out different coloured rock masses according to solidification processes. Magmatic, metamorphic and sedimentary rocks with various chemical compositions can be explored around us together with their original rock colours and weathered surface parts' colours. When rock mass related engineering activities have more been concentrated on rock weathering, engineers have studied more closely on rock surface colours. Because rock surface colours are first distinguishing factors to visualize rock weathering influences on the selected rock surfaces. While weathering has been slowly advanced in/on the rock masses, related rock surfaces have gradually altered their colours. Weathering of rocks covers progressive complex reactions which have been taken place under particular environments (deep or shallow locations in the earth crust; sometimes at the earth surface) influenced by gravity, pressure, bioactivity, radioactivity, heat, chemical reactions, climate etc. In rock mechanics concerns, most of the weathering activities have generally influenced rock mass mechanical properties. It is negative effect in general. Therefore any excavation works in or on rock masses which includes stability analyses, should cover detail rock mechanic tests for original and weathered parts of projected rock masses.

In nature, it is difficult to find massive rock masses, Rock masses in general have discontinuities and defect zones. Most of the discontinuities in rock masses are also passage ways of groundwater which has slurry type composition. Groundwater circulating in rock masses includes chemically dissolve materials and it may show basic or acidic activities in different strength. When the rock masses have contacted with groundwater slurry at their discontinuities, colours of contacted rock mass surfaces have gradually differentiated. Therefore, rock mass outcrops and rock discontinuity surfaces are main weathering locations in the rock masses. Clayton et al. (1982) mentioned that chemical rock weathering processes fully depend on the presence of water in or around the rock masses and this type of weathering result in the alteration or dissolution of the component minerals grains. They said that "the chemical decomposition of the rock material starts at discontinuity walls and works inwards towards the centre of the intact blocks". Rock weathering can be recognized by rock surface discolouration. Original rock surface colours may start to change gradually as weathering activities progressed. Therefore each engineering project located in/on rock masses should cover also rock mass discontinuity analyses. Aperture, spacing, orientation, fillings, undulation, roughness, moisture, groundwater seepage level, unconfined compressive strength of discontinuity surfaces, colours and textures observed on original and weathered rock surfaces are the other parameters which project engineers have to be informed. Colours of rocks and colours of discontinuity surfaces have long been used in quick, practical and descriptive identification of rock masses and rock surface weathering.

Rock colours and rock forming mineral colours have possibly been coded by using Munsell colour charts (Munsell, 1905; Cleland, 1921; Munsell Colours, 2017). Usage of this charts have brought widespread applications during identification and naming of rocks and minerals. This is one of earliest method to describe the same rock colours with the same digital codes which eliminates complexity in colour identification. Rock outcrops around us have their own surface appearances and colours, which might be a little different than the original colours of that particular rock mass. Rock surface colours have been affected by several natural influences like; climate effects, micro-organism attacks, chemical weathering, radioactive decaying etc. When the rock masses are forced to be broken down from their corners, its original colours can be seen in deep parts of the rock fragments where there is no weathering effect at all. This is one of the means how engineers can recognize the colour differences of weathered and original rock surfaces. If there are colour changes on these surfaces and if these can be recognized by naked eyes, these differences can also be codified by using Munsell charts or similar colour systems. In 
order to eliminate irregularities occurred in colour tones identification due to human eyes capacities, colour digitizing method have recently been employed for engineering applications. This method produces standard colour reading outputs by using high definition colour photographs. There are several systems describing colours like; CAM, CIE, RGB, YUV and others (CMYK, Colouroid, HSV, HSl, $\mathrm{HCl}$ etc.). Rock surface colours obtained from weathered or original rock surface in this study were analyzed in RGB colour system. Rock surfaces were photographed in daylight and filed in computers according to their locations and rock mass types. Digitizing these images and obtaining RGB colour codes were the second steps in this work. During this study, high quality photographic images taken from six different locations including open pit mines, quarries, hydraulic dam construction sites, village road cuts were used to analyze colour differences between original and weathered rock surfaces. The aim was selected here to present these colour differentiation for the selected rock masses.

\section{COLOUR ANALYSES APPLIED FOR ROCK MATERIALS}

Colour changes of rock surfaces happened during natural weathering progress have not searched in detail. On the other hand weathering of rock masses have been recognized as one of the main strength decreasing factors for rock masses. When underground openings, open pit slopes, civil purposed tunnels are planned in/on the weathered rock masses, engineers test these rock masses by using test samples taken from fresh and weathered parts of them. Similarly, dimensional building stones used for houses, pavements, parks, etc have also been tested for their strength. Building stones should not be cut from weak weathered rock masses. Moreover, these kinds of rock usages should be tested for their weathering strength according to their position of usage in construction industry. Hence identification of weathered parts of rock masses has always been an important. Clayton, et al. (1982) stated that weathering of rock may be detected by controlling their weathered parts' strength and colours. They wrote that "In many cases the most noticeable effect of weathering at the rock material scale will be discolouration and/or weakening adjacent to discontinuities". This statement stresses on the importance of original rock masses colours and their discolouration due to weathering. Clayton et al. (1982) especially mentioned the rock colour chart produced by Geological Society of America (1963). They wrote that, since the original colours of rock masses fully depend on associated mineral composition of the constituent particles or the cementing material (in the case of sedimentary rocks), these colours should be identified accurately without causing any further misleading. According to them researchers had earlier been worked on rock weathering to provide classification scheme. One of them for example concentrated on chemical weathering of granitic rocks (Anon, 1970). In later years, Geological Society of London (1977) organized a "Working Party of Engineering Group" to define effects of rock weathering. They described weathering for rock material (micro) and rock mass (macro) scales. As the engineering projects had been commissioned to construct in/on rock masses in modern world, intact and weathered rock differences and their identification have became important. As Clayton et al. (1982) reported that British Standard (BS 5930:1981) in this respect, offered to use following terms for weathered rock materials; decomposed, disintegrated, fresh and discoloured to order engineering usage of weathering terms. Importantly, "no guidance for determining and describing the degree of weathering" was also reported for this BS standard by these researchers. However, it demonstrated that rock decolourisation in nature is important stage in rock weathering activities.

Eggleton et al. (1987) were also studied rock weathering by concentrating on basalts. They stated that main weathering action they had been revealed was dissolution process. According to them plagioclases are weathered initially along fractures and cleavage planes. This weathering activities cause decolourisation (yellowing) of the related rock surfaces. They reported that "the colour change is largely caused by a change in the colour of the palagonite from yellow to orange-red and by the complete replacement of olivine and pyroxene by a dark-red, isotropic alteration product, predominantly goethite". Some other rock types have also been analysed for their weathering characteristics. Andesite located near Ankara (Turkey) for example evaluated by Karpuz and Pasamehmetoglu (1997) for their 
weathering properties as well. They suggested idealized weathering profile and the scale of rock mass weathering grades. They described andesite rock masses in special terms, each shows andesite weathering levels; These terms are; colour, grain size, structure-texture, block size-shape, discontinuity spacing, weathering stage (hydrothermal alteration etc.), minor lithological characterization (layering, fracture, strength) and other additional characteristics (such as; discontinuity conditions, fillings, dominant joint sets, existence of hydrothermal alteration, etc.). Time effect on rock weathering is important. How long the fresh rock surfaces have been stayed under the weathering actions is other consideration parameters. Figure 1 shows here two graphical results given by Yokoyama and Nakashima (2005). These two researchers analysed colours of four rhyolites which have different volcanic eruption times (1100, 1800, 26000 and 52000 years ago) in Kozushima Island in Japan. They determined that these eruptions have similar chemical compositions at the time of eruption. This means common colours around the volcano was whitish lava colours just after each eruption. As it was stated in Yokoyama and Nakashima paper, the surface colours of these rhyolites were different in 2005 due to weathering effects in time. Since these rhyolites had been formed in different volcanic eruptions, oldest rhyolites have more yellow-brownish weathered rock surface colours. According to the researchers, colour changes which have gradually been arisen at rhyolite rock masses indicate the formation of iron (hydr) oxides on their surfaces.
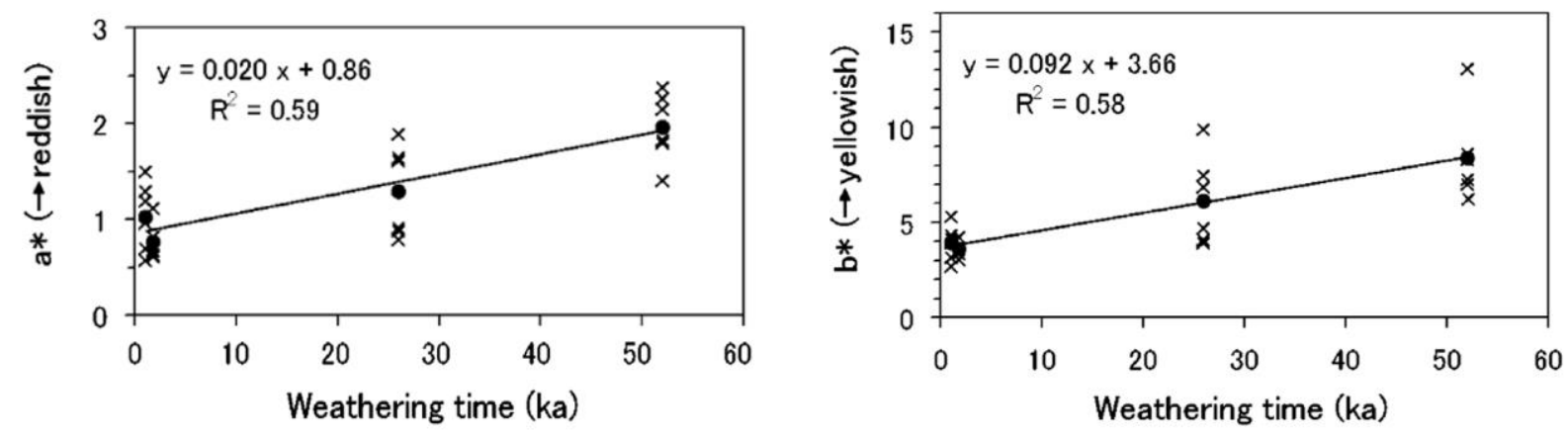

Figure 1. Rock powder colours ( $\mathrm{a}^{*}$ and $\mathrm{b}^{*}$ colour values of L.a.b. colour system) determined from rhyolites samples were plotted here against total weathering time $(k a=(x 1000)$ years $)$, (Yokoyama and Nakashima, 2005).

Chemical composition changes on the surfaces of rock masses where the weathering actions are more predominant differentiate rock surface colours. However there are other factors forcing the rock surface colour changes. For example Annerel and Taerwe (2011) examined colour changes of concrete structures exposed to fire. They applied HSI and CIE Lab colour space to obtain these changes in digital manner. They reported an elliptically shaped colour path changes. In some cases, weathering of rock materials have been analysed by using "ageing tests" like Heidari et al. (2017). They compared different ageing effects by using fuzzy inference system to estimate weathering degrees on monument stones of three historical sites in Iran. Ageing tests they performed on fresh rock materials were a) freeze-thaw, b) thermal shock, c) salt crystallization, d) dissolution and e) wetting-drying. These are the climatic influences on building stones which may cause severe weathering. Grossi et al. (2015) studied weathering degree of Itaquera Granite used for historical the Ramos de Azevedo monument in São Paulo, Brazil. They had monitored colour variation of granite on this monument to compare rock surface colours obtained from fresh granite surfaces which were mined from the same historical granite quarry. Colour values had been determined in this study for a while to understand effects of time and pathologies. Weathering effects (yellowing) on the monument's granite surfaces were determined as; oxidation of iron-rich minerals, pollution influences, biological colonization, leaching of bronze statue over the granite base, and the dissolution-precipitation of monument mortars. 
Weathering effects and colour changes on building stones are become common research activities after general acceptance of historical sites and their cultural values. Vazquez, et al. (2016) researched on six natural building stone types to understand weathering effects on them. They performed aging tests on these rock samples. Samples were exposed to four strong acidic atmospheres consist of the following acids: $\mathrm{H} 2 \mathrm{SO} 3, \mathrm{HNO} 3$, and two mixed solution with different proportions of $\mathrm{H} 2 \mathrm{SO} 3$ and $\mathrm{HNO}$. They recorded; weight, colour, roughness and microscopic feature changes on the tested rock surfaces. They reported sample surface colour changes in L.a.b. colour system. In this colour analyses; " $\mathrm{L}$ " is lightness, "a" and " $b$ " are colour channels where; "a" scales green-red colour values; " $b$ " scales yellow-blue colour values (Hunter, 1948; Hunter-Labs, 1996). The graphs in Fig. 2 illustrate colour variation occurred during their ageing processes. This graphs show also that, even rock weathering factors are under control, the resultant colour changes happened on rock surfaces can be different. This shows also that rock types and properties are also main governing factors in weathering processes.
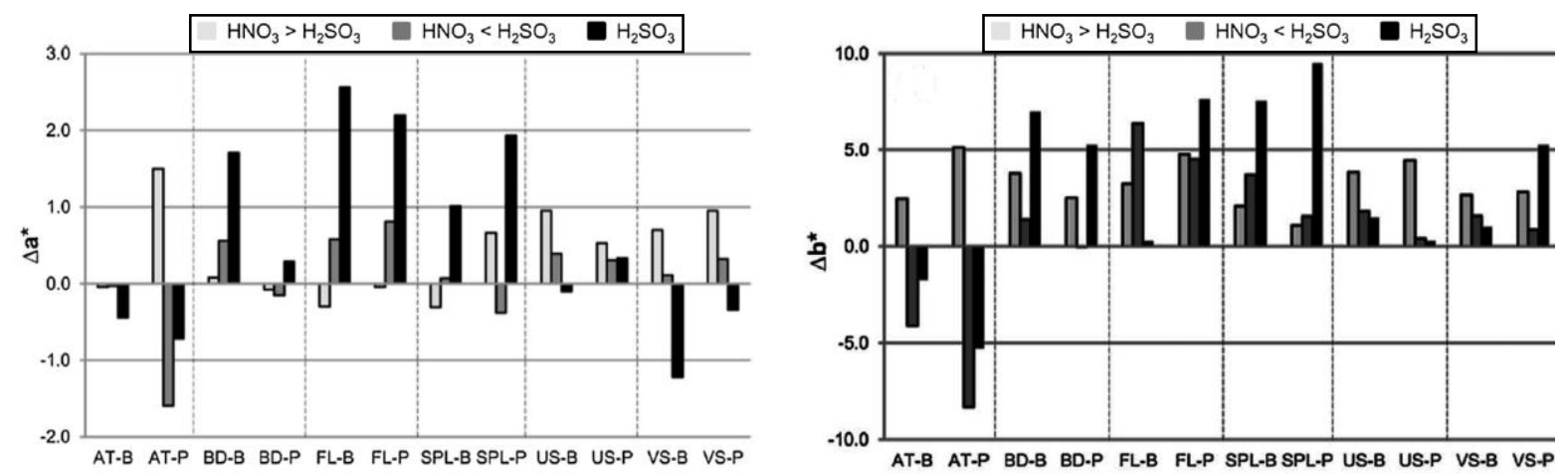

Figure 2. Variations in colour parameters "a" and "b" (in L.a.b. colour space) after each ageing test for the "bush hammered finish, (B)" and the "polished finish, $(\mathrm{P})$ " natural stones. (Test samples were codified as; AT: Albox travertine, BD: Boñar dolostone, FL: Fraga limestone, SPL: Santa Pudia limestone, US: Uncastillo sandstone, VS: Villaviciosa sandstone), (Vazquez, et al., 2016).

Borrelli et al. (2007) analysed the relationship between rock mass weathering grades and slope instabilities. To reach this aim they prepared weathered rock maps for their project, study, areas. One of the factors they controlled in their field works was discolouration of the rock surfaces. They recorded discolouration of rock mass as; completely, partially, along discontinuity or none. After that, they combined all rock mass related data to decide on rock masses' weathering grades. In computer colour analyses, colour systems have recently been used to digitize natural and industrial material's colours. As Patel and Chatterjee (2016) stated that the study of computer vision-based rock-type classification is limited. Thus, they developed a computer vision-based rock-type classification algorithm to achieve consistent raw material classification for cement industry. In this work, Patel and Chatterjee utilized computer based RGB colour recognition systems and colour image histogram-based features to recognise rock types inputting to cement factory as a raw materials.

\section{DEGREE OF ROCK SURFACE WEATHERING}

Differences in colours of rock masses illustrate certain property differences and this can be used by engineers in mining and civil engineering fields. Rock weathering and appeared colour intensity on rock mass surfaces have long been used to classify them in visual bases. Colour changes due to rock weathering on the other hand analysed digitally here in this study to evaluate if there is any colour related features. In order to realize any common attributes, fresh rock surfaces and weathered rock surfaces of the same rock types have been tested for their colour changes. Since limestone layers can easily be reached around Konya (Turkey), first colour analyses were performed for limestone 
formations. Most of the outcropped limestone layers here have white, white to light gray, white to beige and gray in colours. These limestone layers are fractured and most of the open fractures near the surface had been filled by overburden materials. These materials are generally soils, decomposed rocks or their influents which are facilitated chemical weathering process in these discontinuities.

A research area in this study was decided then to explore digital RGB colour codes of fresh and weathered rock mass surfaces. The question here is; "if there is any pattern or relation in rock decolourisation during weathering procedures". Weathered rock surfaces may get their colour in randomly progressed chemical reactions on those surfaces. In order to explicate colour change patterns at rock surfaces due to weathering, observations obtained from the rock masses outcropped around Konya regions were used. These tested rock masses were limestone, serpentine, andesite, travertine and tuff rocks.

In order to digitize weathered rock surface colours, first test site was selected at hard crystalline dolomitic limestone outcrop. It is Silurian-Devonian era rock mass (Eren, 1993) and it has dark gray in colour. This rock outcrop is located at $30 \mathrm{~km}$ away from Konya city centre. It was embodied at the North side of Konya-Yukselen village road. Since this limestone has high strength, hydraulic hammers were used to obtain enough space to construct village road. Due to these rock fragmentation techniques, road cut slopes at test location have fresh rock surfaces similar to the ones illustrated in Fig. 3a. Weathered rock surfaces in this location were generally discontinuity surfaces where some of them were day lighted due to road cut rock fragmentation. As it is seen at Fig. 3b, weathered dolomitic limestone surfaces here have light brown to light reddish or brownish in colours. Differences in weathered dolomitic limestone colours are mostly related with degree of decomposition and weathering levels.

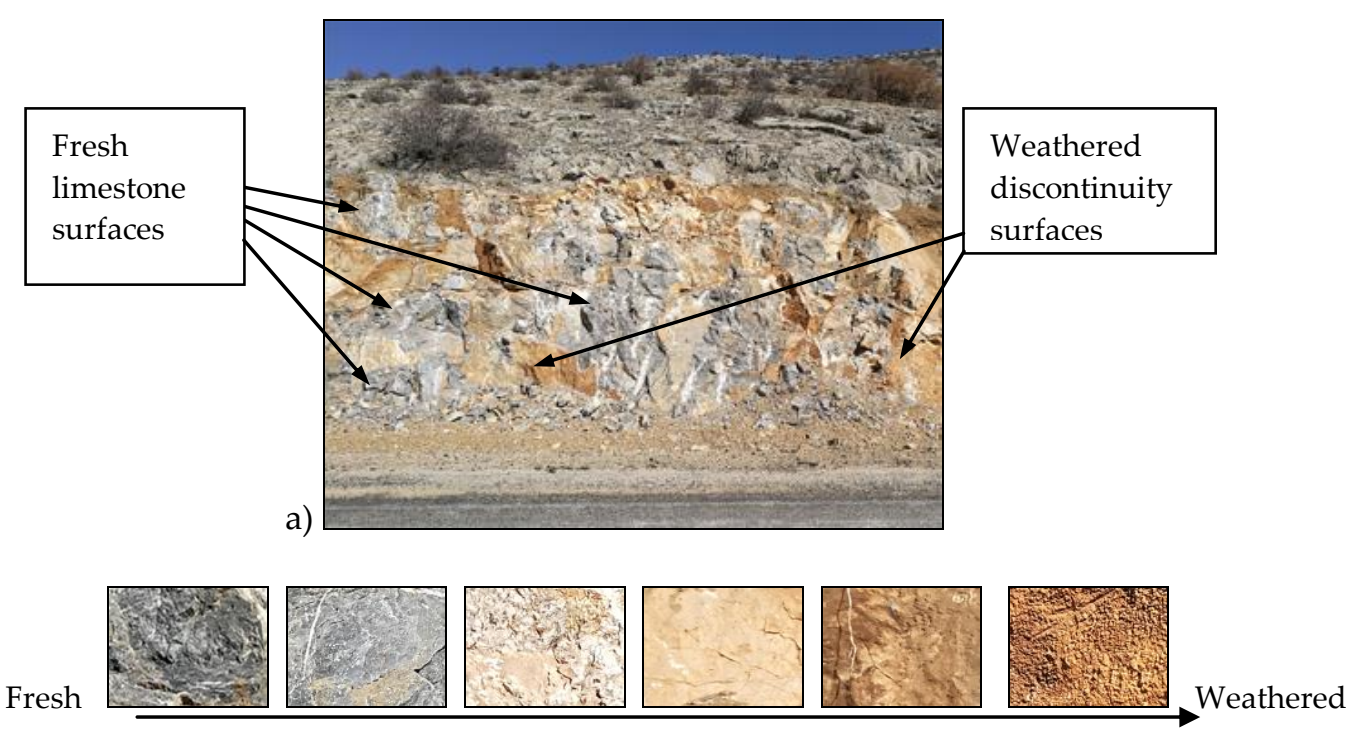

b)

Figure 3. Fresh and weathered limestone surfaces at Konya-Yukselen road cut.

Colours at weathered rock surfaces in these images were determined and they were differentiating from light brown (light beige) to dark brown. Defining these colours and their tones differences in "words" bring always complexity in engineering communications. Referring common pre-defined charts like Munsell colour charts and tables in colour description have been one solution to this complexity. These types of colour identification methodologies can be called "colour comparison-colour matching" methods. They require obviously fine printed colour charts or booklets and healthy eyes. It should be mentioned here that the capacity of human eyes to differentiate colours and their tones are different among human beings. Because of these irregularities, colour analyses in industry have gradually been facilitated by finer equipments and machines. Colour sensors, cameras and computers are used today to define colours and their tones. In this research, images of rock surfaces were photographed by camera lens which have 20 megapixels in monochrome and 12 megapixels in RGB format capacity. 
Table 1. Digitized RGB colours of dolomitic limestone rock mass located at Konya-Yukselen road cut, (Total data contains 93 lines of RGB readings but, this table presents only 5 lines of them as an example).

\begin{tabular}{|ccc|ccc|}
\hline \multicolumn{2}{|c|}{ Fresh limestone surfaces } & \multicolumn{3}{c|}{ Weathered limestone surfaces } \\
Red (R) & Green (G) & Blue (B) & Red (R) & Green (G) & Blue (B) \\
\hline 134 & 129 & 122 & 59 & 33 & 17 \\
166 & 155 & 144 & 127 & 82 & 48 \\
119 & 110 & 98 & 141 & 93 & 54 \\
128 & 127 & 127 & 99 & 67 & 38 \\
180 & 176 & 170 & 126 & 93 & 67 \\
\hline
\end{tabular}

After saving original pictures in JPEG file format into computers, selected parts of the images are analysed for their colour identifications (Table 1) by using MRA colour analyses program. This software was especially developed to define rock surface colours and their colour distribution homogeneities, (Gokay and Gundogdu, 2008). The RGB data, (obtained from 93 micro pixel-based areas), were then used to analyze colour changes by 2D and 3D graphics. These graphics were drawn by using Excel together with Xlstat-3D module (2017). Colour coding in RGB format defines totally $(t=255 \times 255 \times 255)$ $16,581,375$ tones of colour values. This number of tones is seemed to be higher than the human eyes can handle in repetitive manner. In RGB codification, maximum and minimum limit values and their representing colours are as follows; RGB value of $(0,0,0)$ represents total blackness, $(255,255,255)$ value represents total whiteness in colour. Figure 4 shows that there are obvious graphical differences between fresh and weathered dolomitic limestone surfaces analysed here. Actually, original, fresh, colours of this rock mass at the selected slope of Konya-Yukselen road cut (Fig. 3a) are dark greyish in colour. Therefore colour data obtained from these fresh dolomitic limestone rock surfaces have graph points (square shaped data points) at graphics shown in Fig. 4 which can clearly detachable from the plot points representing weathered surfaces' colours (rectangular shaped data points). RGB data obtained from weathered dolomitic limestone surfaces produced scattered graph points as seen in Fig. 4 . However when these graphs analysed in detail, (in other words when the weathered rock surface colours and observed weathering degrees were compared), it could be concluded that more weathered surfaces in this road cut location provide graphs' points closer to graphs' origin, (near to $(0,0)$ values). Similarly when the plotted colour data points are observed closer to $(255,255)$ colour values in Fig. 4 , the colours of dolomitic limestone weathered surfaces were observed for them as light-brownish (lightbeige) which also means less degree of weathering.

At the earlier work performed at the same dolomitic limestone slopes, Gokay (2003) pointed out that fresh and weathered rock surfaces provided different chemical compositions. Samples obtained from fresh, (Fr), and weathered, (wth), surfaces were tested for their chemical compositions in that study and selected dominant chemical compounds were reported with the following composition values. These results (in percentage) are presented here for fresh rock (Fr) surfaces, weathered rock (wth) surfaces and discontinuity filling material (fill) as follows; $\mathrm{CaO}$ (Fr: 55.74 - wth: 49.78 - fill: 17.98), $\mathrm{Al}_{2} \mathrm{O}_{3}$ (Fr: 0.17 - wth: 2.44 - fill: 8.44), $\mathrm{Fe}_{2} \mathrm{O}_{3}$ (Fr: 0.24 - wth: 1.09 - fill: 6.07), $\mathrm{MgO}$ (Fr: 0.46 - wth: 5.23 - fill: 11.42) and $\mathrm{SiO}_{2}$ (Fr: 0.89 - wth: 4.66 - fill: 33.45). That means; weathered rock surfaces shown in Fig. 4 have higher concentration of the following compounds (multiplication values=wth/Fr); $\mathrm{Al}_{2} \mathrm{O}_{3}(14.35), \mathrm{Fe}_{2} \mathrm{O}_{3}(4.54), \mathrm{MgO}$ (11.36) and $\mathrm{SiO}_{2}$ (5.23). $\mathrm{CaO}$ concentration on the other hand was found lower for weathered rock surfaces, $\mathrm{CaO}$ (0.89). Combination effects of these chemical compound differences on dolomitic limestone rock surfaces should be the main reason of the colour changes due to weathering.

In order to understand the differences in weathered rock surface colours, originally whitish coloured (white, light gray, light beige) limestone outcrops in North-West side of the Konya city was also taken into evaluation. This limestone formation has Late Myosin-Early Pliocene aged (Eren, 1993) and it has gray-beige fresh surfaces. It contains very small amount of clay minerals in its composition as well. As it is seen in Fig. 5, rock weathering has been occurred here at the surface of discontinuities. Terra-rosa soiling activity and seepage of their influent into this limestone layers (Fig. 5) have been main 

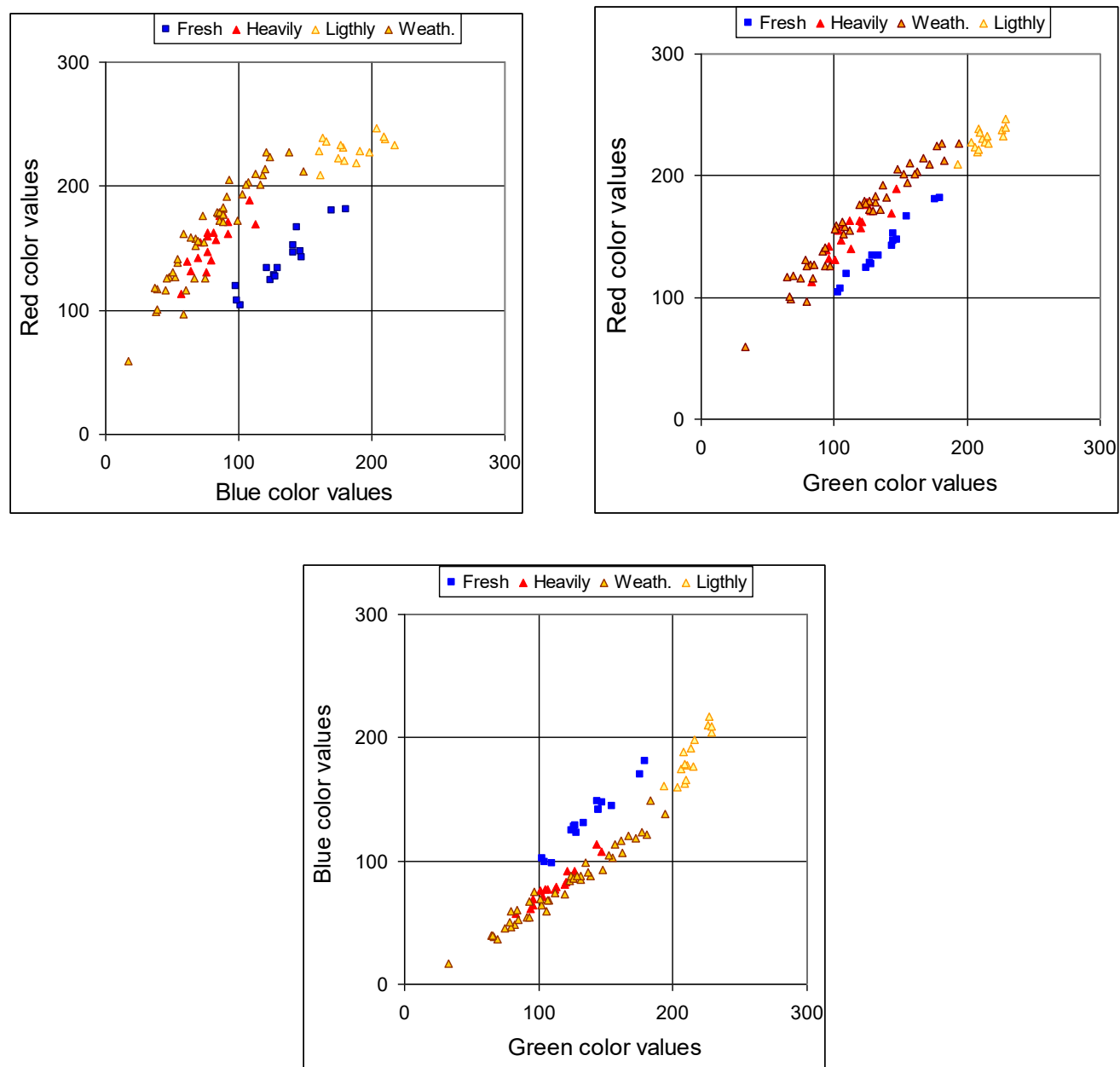

Figure 4. Selected colour-band graphics for digitized RGB data obtained from fresh and weathered dolomitic limestone surfaces (tested at Konya-Yukselen road cut).

weathering factors. Main differences between these two sets of data which were obtained from dolomitic limestone $\left(1^{\text {st }}\right.$ case) and beige coloured limestone $\left(2^{\text {cd }}\right.$ case) rock masses were their colours and compositions. Main chemical compound was $\mathrm{CaO}$ but there are many others which influence on their naming and weathering progress. In first case, the rock mass is dolomitic limestone therefore fresh rock surfaces are blackish, dark gray, with crystalline characters. In second case the rock mass is lake deposited limestone, its fresh rock surfaces are light gray, beige, and beige to gray in colour. Due to different sedimentation and tectonic conditions, (which they have been passed through in geological eras), their fresh rock colours gradually changed in some parts of them due to weathering actions. When the images given in Fig. 3a and Fig. 5a were analyzed, it can be seen that weathered parts of the rock masses have different colours with respect to fresh rock surfaces. Weathered rock colours are usually identified at these rocks' discontinuity surfaces and their day lighted surfaces. Total colour data obtained from lake deposited, beige coloured, limestone rock mass contain 87 points' RGB values. Each colour datum contains R, G, and B colour values separately. Selected colour band graphics supplied for beige coloured limestone, demonstrate weathering decolourisation (Fig.6) as well. That is as weathering effects were observed intensive, the colour codes obtained from weathered beige coloured limestone were plotted gradually towards the dark colour zones, (near to origin of graphs), of RGB colour graphics. However dolomitic limestone and beige coloured limestone have different graph point locations for their fresh surface colours (Fig. 4 and Fig. 6). Unlike the colour of beige limestone, (Lst-2, fresh surface colours were plotted near whiteness corners, 255,255,255), crystalline dark gray, dolomitic limestone, (Lst-1) produced fresh surface colours which have plot points near the blackness corner, $(0,0,0)$. 
a)

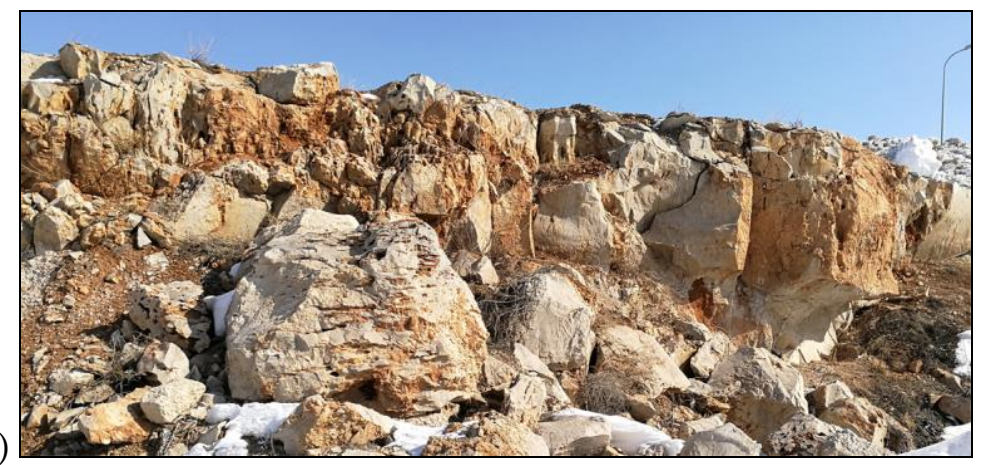

Fresh

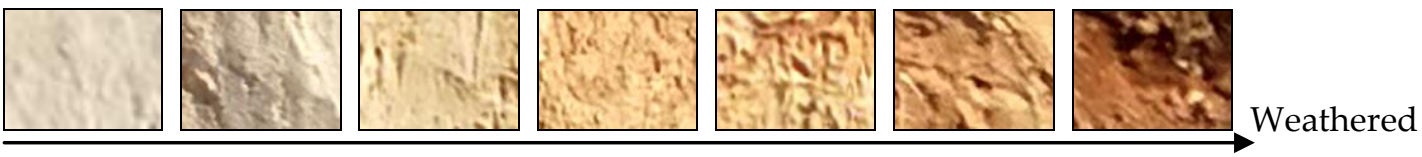

b)

Figure 5. Fresh and weathered limestone surfaces and their colour differences at North-West side of Konya city centre.
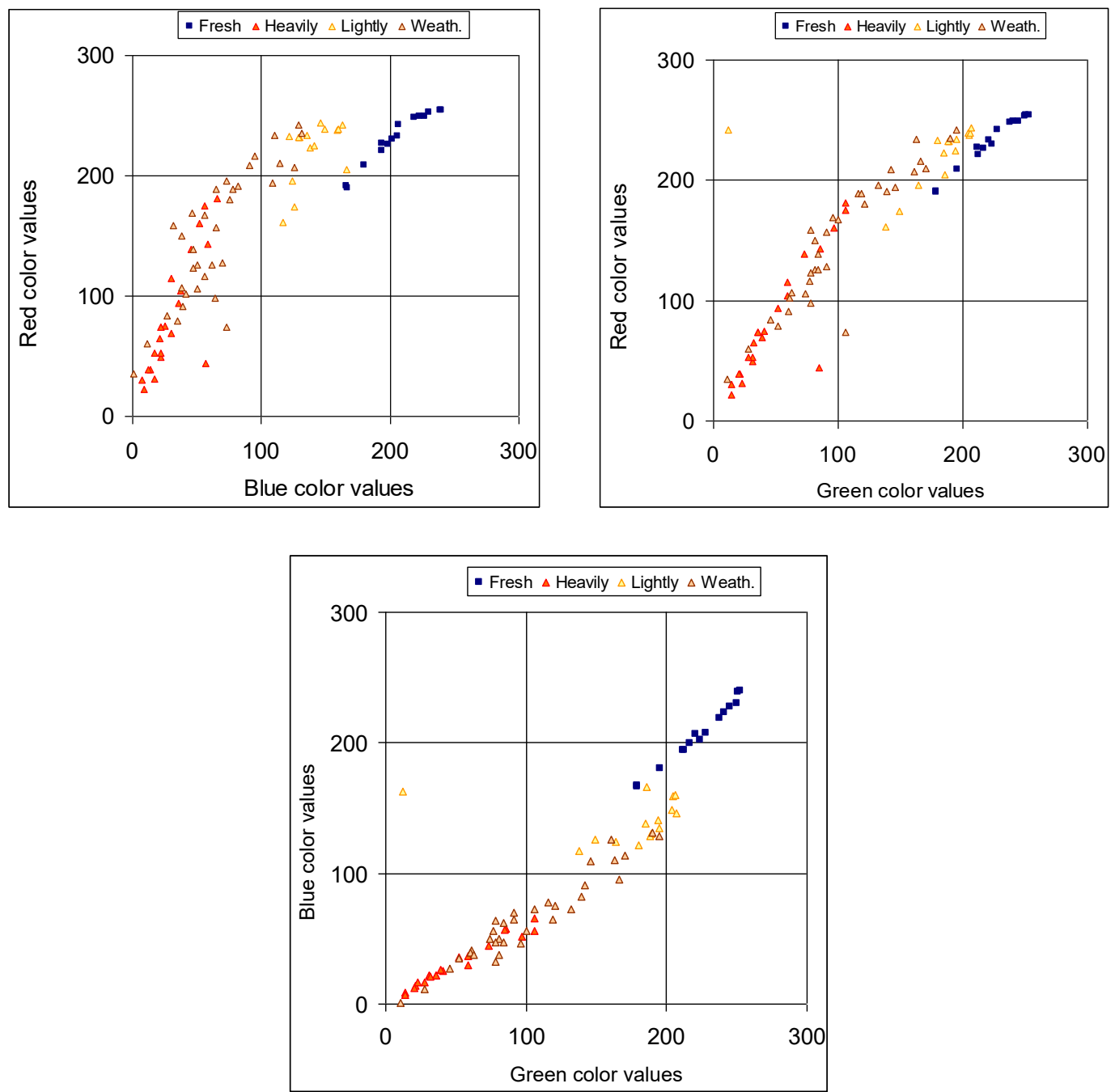

Figure 6. Selected colour-band graphics for digitized RGB data obtained from fresh and weathered beige limestone surfaces. This rock mass is located at North-West side of Konya. 
Graphics presented in Fig. 4 and 6 exhibit colour value plots which seem to have distribution relations. These two figures show that fresh and weathered rock surface colours of certain rock masses can be identified as colour groups named as; fresh, lightly-weathered, weathered, and heavily-weathered.

\section{COLOUR CHANGES AT ROCK MASS SURFACES IN GENERAL}

Colour determination research study was performed here for limestone rock masses include fresh and weathered rock surfaces' colours. This study was then decided to extend other rock mass types outcropped around Konya region. In order to analyse the colours of fresh and weathered surfaces of these rock masses, required high quality photographs were obtained from them and evaluated accordingly. Colour changes due to weathering actions were researched for the following rock masses as well; a) Limestone formations, Lst-3, (Konya cement factory-Limestone quarry, Konya), b) Limestone formations, Lst-4, (aggregate quarry North site of Konya), c) Limestone rock clift, Lst-5, (landslide area, Taskent, Konya), d) Limestone formations, Lst-6, (hydraulic dam construction site, Ermenek, Karaman), e) Andesite formations, And-1, (dimensional stone quarry, Sandikli, Afyon), f) Tuff formations, Tuff, (Evliyatepe, Konya), g) Travertine formations, Trav-1, (abandoned open mine, Ardicli-Konya), h) Travertine formation, Trav-2, (abandoned open cuts, Esentepe-Konya) i) Serpentine formation, Serp, (Dere village connection road cut, Meram-Konya).

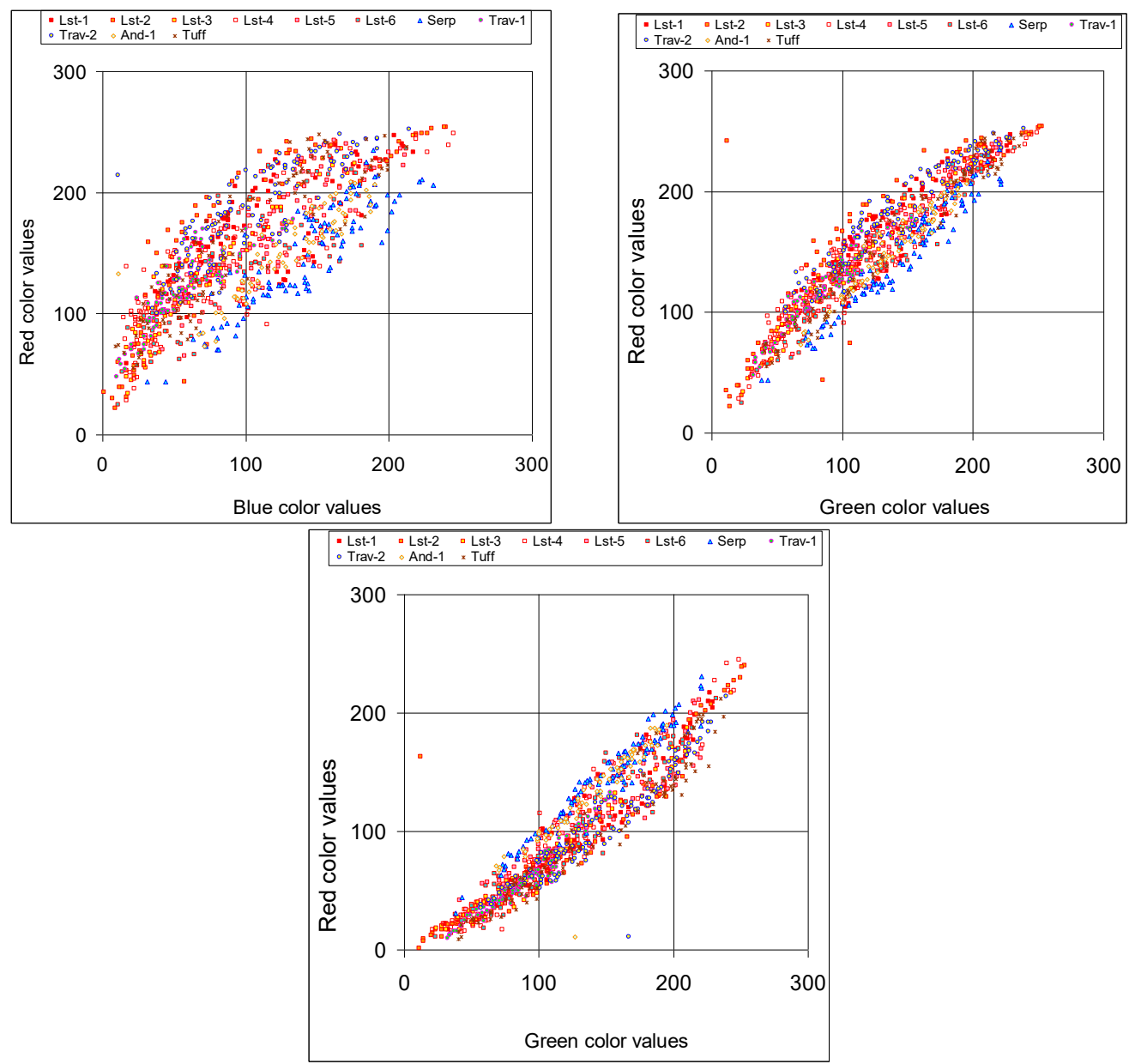

Figure 7. Selected 2D colour-band graphics for digitized RGB data obtained for fresh and weathered rock masses around Konya region; [Limestone formations (Lst-1: Konya-Yukselen road cut, Lst-2: North-west side, Konya, Lst-3: Cement factory quarry, Konya, Lst-4: Limestone aggregate quarry, Konya, Lst-5: Landslide area, TaskentKonya, Lst-6: Hydraulic dam construction area, Ermenek-Karaman, Serp: Serpentine rock mass outcrops, Dere village, Meram-Konya, Trav-1: Travertine mine, Ardicli-Konya, Trav-2: Abandoned travertine mine, Esentepe-Konya, And-1: Andesite dimensional stone quarry, Sandikli-Afyon, Tuff: Crystalline tuff mine, Evliyatepe, Konya)]. 

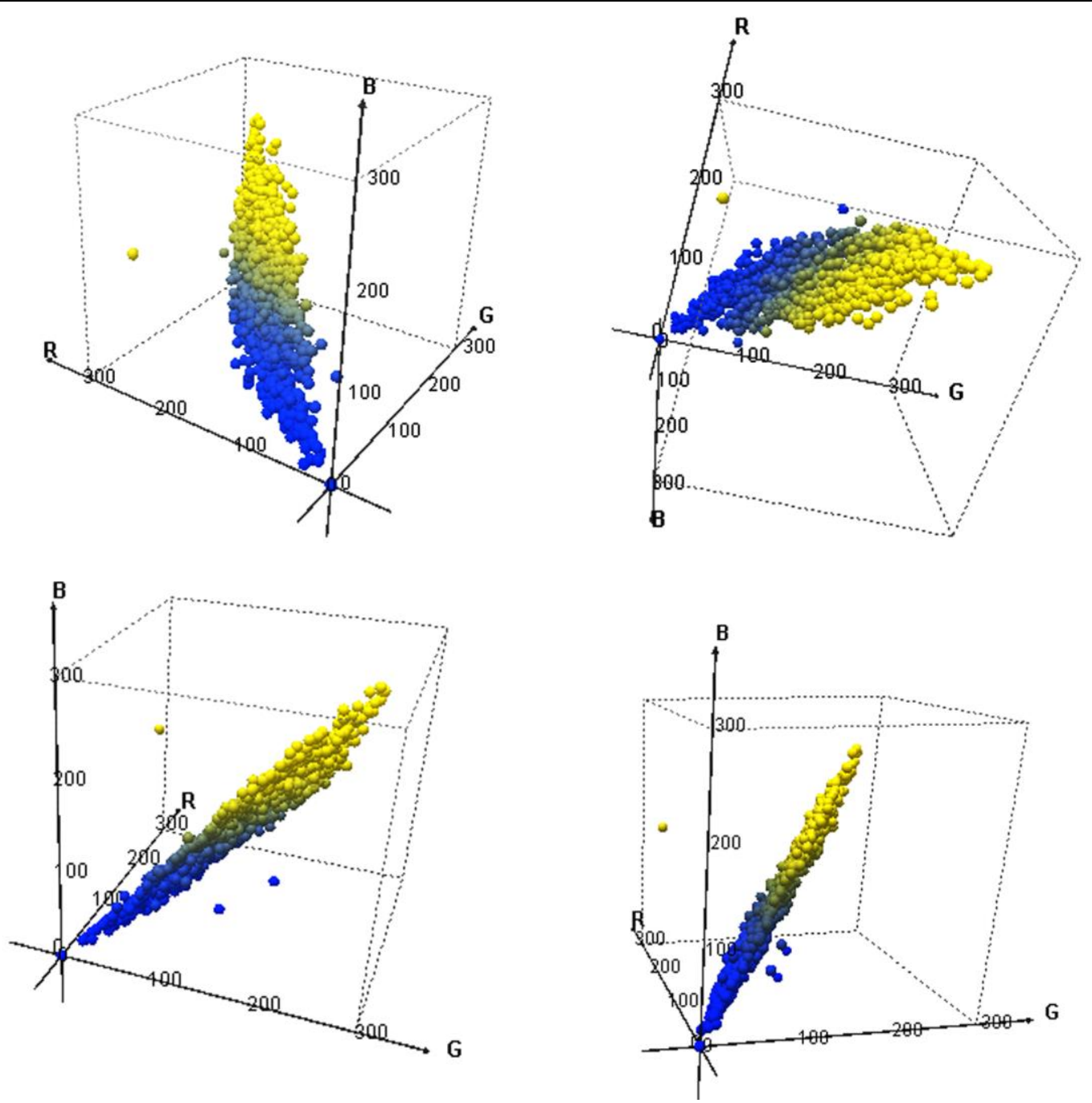

Figure 8. Colour data collected from the rock masses around Konya region were used to obtain these 3D graphs. Fresh and weathered rock masses' (limestone, serpentine, andesite, travertine and tuff formations) colours were all handled (totally 1009 colour data) here to obtain these plotting.

When the digital RGB colour determination of fresh and weathered rock surfaces were realised, their selected band colour graphics were plotted (Fig.7). In order to capture rock surface colours, certain surface area were selected from rock surface images in micro-pixel, scale. Average RGB colour codes were then calculated and recorded for those micro areas. Total number of micro-pixel areas was 1009 for the tested 11 different rock mass locations. Selected colour band graphics of whole test data for RGB colour codes were then plotted to verify general colour distribution in 2-dimension. These graphics have axis of Red-Blue, Red-Green and Blue-Green (Fig. 7). In order to understand 3-dimensional RGB colour changes due to rock mass weathering, whole colour data were used to achieve 3-D graphs as illustrated in Fig. 8. Graphics in Fig. 7 and Fig. 8 show clearly that, colour differentiation due to rock weathering in these 11 rock mass locations has elliptical volumetric shape. Colour distributions in Fig. 8 are not seemed to be randomly distributed. It is obvious that; absolute black colour value has coordinate RGB values as 0,0,0 and absolute white colour value has coordinate RGB values as 255,255, 255, these two minimum and maximum colour coordinate values should definitely be the pointed limits of formed volumetric shapes. That is, volumetric shape covers all the plotted points appeared on 3-D colour graphs for rock colours should obviously have these two pointed ends at minimum and maximum values. When Fig. 8 was evaluated with this concept, two flattened, half-parabolic cone shapes which are pointed opposite 


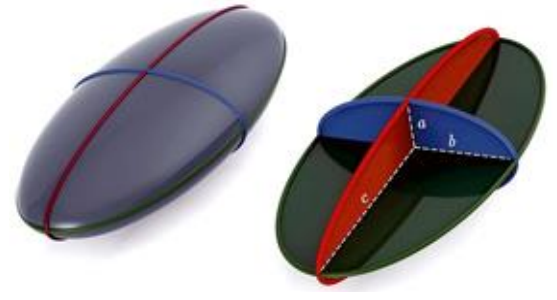

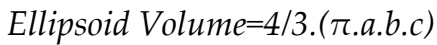

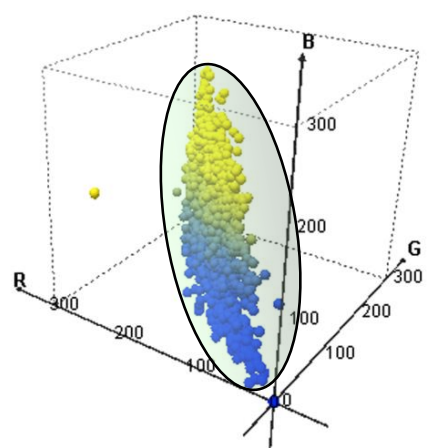

Figure 9. Triaxial-ellipsoid volume (Wikipedia, 2012), and its coverage in the selected RGB colour space.

coordinate end points $(0,0,0$ and $25,255,255)$. These 3D plotted colour points can also be encapsulated with a volumetric shape looks like triaxial-ellipsoid (Fig. 9) as well. This encapsulated volume shapes and their extension limits are further steps to be researched. Since, extension of colour data obtained from fresh and weathered rock surfaces might bring more accurate 3D volumetric explanations in this research.

\section{CONCLUSION}

Mining and civil engineering applications cover engineering projects located in/on rock masses. Exploration works on these project sites include rock identifications, rock mechanical tests, discontinuity research etc. Engineers in these fields have their projects on; mining galleries, tunnels, metro stations, open pit slopes, road cut slopes, cliff stability, foundation stability of all engineered constructions, underground openings, big scale underground excavations, cave stability, highways and railways etc. Thus they have well experienced about fresh and weathered rock mass property differentiations. Weathered rock zone usually means weak stability and decoloured rock surface sectors in rock masses. In this study, fresh and weathered rock mass surface colours were analysed to define their colour differences. It is obvious that, fresh rock surface colours are discoloured while different types of weathering activity (in/on earth crust) have been progressed. Colour tests had been performed on eleven rock mass locations in this research. Fresh and weathered surfaces of rock masses located there were digitized for their colour analyses. It was evaluated that rock surface colours obtained during this study produced 3D graph points which can be encapsulated by means of triaxial-ellipsoid volume. That means, these colour data demonstrated certain distribution patterns (limitations) in RGB colour graphics. Actually, this statement needs further colour tests on other types of rock masses as well. However, major rock masses observed near Konya city provided the presented graphical results as illustrated in Fig. 7 and 8. Determination of triaxial-ellipsoid dimensions and influences of weathering types on these dimensions can be further studies realized.

\section{REFERENCES}

Annerel, E., Taerwe, L., 2011, "Methods to Quantify the Colour Development of Concrete Exposed to Fire", Construction and Building Materials, Vol. 25(10), pp. 3989-3997.

Anon, 1970, “Using a Remotely Controlled Borehole Camera”, Ground Engineering, Vol. 3(5), pp. 20-21.

Borrelli, L., Greco, R., Gullà, G., 2007, “Weathering Grade of Rock Masses as A Predisposing Factor to Slope Instabilities: Reconnaissance and Control Procedures", Geomorphology, Vol. 87, pp.158175.

Clayton, C.R.I., Matthews, M.C., Simons, N.E., 1982, Site Investigation, Second Edition, Department of Civil Engineering, University of Surrey, Halsted Press, p466.

Cleland, T.M., 1921, "A Practical Description of the Munsell Colour System, with Suggestions for Its Use", Munsell Colour Company, Boston, USA. 
Eggleton, R.A., Foudoulis, C.,, Varkevisser, D., 1987, “Weathering of Basalt: Changes in Rock Chemistry and Mineralogy", Clays and Clay Minerals, Vol. 35(3), pp. 161-169.

Eren, Y., 1993, Eldes-Derbent-Tepekoy-Sogutozu (Konya) Regions' Geolgy, PhD Thesis, Selcuk University, Department of Geological Engineering, Konya, Turkey.

Geological Society of America, 1963, "Rock Colour Chart", Geological Society of America, www.geosociety.org, Boulder, CO, USA.

Geological Society of London, 1977, "The Description of Rock Masses for Engineering Purposes", Engineering Group Working Party Report, Q. J. Eng. Geology, Vol. 10( 4), pp. 355-388.

Gokay, M.K., 2003, "Effects of Natural Weathering of Rock Masses on Their Colour Appearances", Madencilik Journal, Turkish Chambers of Mining Engineers, Mining Journal, (technical note), Vol.42, 1, pp. 35-42, Ankara, Turkey. (in Turkish).

Gokay, M.K., Gundogdu, I.B., 2008, "Colour Identification of Some Turkish Marbles", Construction and Building Material, Vol. 22(7), July 2008, pp. 1342-1349.

Grossi, D., Del Lama, E.A., Garcia-Talegon, J., Inigo, A.C., Vicente-Tavera, S., 2015, "Evaluation of Colourimetric Changes in the Itequera Granite of Ramos De Azevedo Monument, Sao Paulo, Brazil", International Journal of Conservation Science, Vol. 6 (3), pp. 313-322, ISSN: 2067-533X

Heidari, M., Chastre, C., Torabi-Kaveh, M., Ludovico-Marques, M., Mohseni, H., 2017, “Application of Fuzzy Inference System for Determining Weathering Degree of Some Monument Stones in Iran", Journal of Cultural Heritage, available online 25 January 2017.

Hunter, R.S., 1948, "Photoelectric Colour-Difference Meter", Proceedings of the Winter Meeting of the Optical Society of America, JOSA, Vol. 38, 7, 661.

Hunter, Labs., 1996, "Hunter Lab Colour Scale, Insight on Colour", (August 1-15, 1996), Hunter Associates Laboratories, Reston, VA, USA.

Karpuz, C., Pasamehmetoglu, A.G., 1997, "Field Characterisation of Weathered Ankara Andesites", Engineering Geology, Vol. 46, pp. 1-17.

Munsell, A.H., 1905, A Colour Notation, G.H. Ellis Company, Boston, USA.

Munsell Colours, 2017, Official Site of Munsell Colour (ㅇ ", X-Rite incorporated web-page, www.Munsell.com.

Patel, A.K., Chatterjee, S., 2016, "Computer Vision-Based Limestone Rock-Type Classification Using Probabilistic Neural Network", Geoscience Frontiers, Vol. 7(1), Special Issue: Progress of Machine Learning in Geosciences, January 2016, pp. 53-60.

Xlstat, 2017, Data Analysis and Statistical Solution for MS-Excel, Addinsoft, Paris, France.

Vazquez, P., Carrizo, L., Thomachot-Schneider, C., Gibeaux, S., Alonso, F.J., 2016, “Influence of Surface Finish and Composition on The Deterioration of Building Stones Exposed to Acid Atmospheres", Construction and Building Materials, Vol. 106, pp. 392-403.

Wikipedia, 2012, Wikipedia web-page, https://commons.wikimedia.org/wiki/File:Triaxial_Ellipsoid.jpg Yokoyama, T., Nakashima, T.S., 2005, “Colour Development of Iron Oxides During Rhyolite Weathering Over 52,000 Years", Chemical Geology, Vol. 219, pp. 309-320. 